鼻涙管由来と考光られた囊胞の一例

鈴 木 知子

\title{
A Case of Nasolacrimal Duct Cyst
}

\author{
Tomoko Suzuki
}

(Saiseikai Fukushima General Hospital)

\begin{abstract}
A rare case of acquired nasolacrimal duct cyst in a 79-year-old male is reported. He complained of nasal obstruction and the protrusion of the right inferior turbinate was observed. CT-scan showed the mass in the right nasolacrymal duct, right inferior turbinate and right inferior nasal meatus.

He had previous history of right dacryocystectomy and facial trauma. The diagnosis of acquired nasolacrimal duct cyst was made from the CT-scan findings and the previous history. Using a nasal endoscope, marsupialization of the cyst was performed under local anesthesia. At his 3month postoperative evaluation, the patient was asymptomatic.
\end{abstract}

Key words : nasolacrimal duct cyst, CT-scan, nasal endoscope

\section{はじめに}

鼻副鼻腔にはさまざまな囊胞性疾患が生じる，先天性 の鼻淚管囊胞の報告はしばしば見られているが，後天性 の鼻淚管霊胞の報告は少なく，発生機序が明確であった 症例の報告はない，今回私は鼻涙管由来之考光られた後 天性の囊胞を診断，治療する機会を得たので，若干の文 献的考察を加光て報告する.

\section{症例}

症例 : 79歳, 男性.

主訴：右鼻閉.

既往歴: 20 歳頃, 右涙囊摘出術. 30 歳頃, 右鼻翼から 煩部にかけて打撲. 60歳頃より高血圧. 70歳時, 一過性 脳虚血発作，右網膜中心静脈分枝閉塞症(網膜硝子体出 血), 老人性白内障.

家族歷：特記すべきことなし．

現病歷：1994年 9 月27日, 肺炎のため内科入院中, 右 鼻閉を主訴に紹介となる。幼児期より右慢性涙囊炎があ り, 20歳頃, 右涙異摘出術施行. さらに30歳頃, 右鼻翼 から頓部にかけて馬に蹴られた既往があり，この後から
徐々に右鼻閉が生じたとのことであった．視診上顔面， 右内眼角下部に陥凹と手術瘢痕があり右涙囊摘出術の瘢

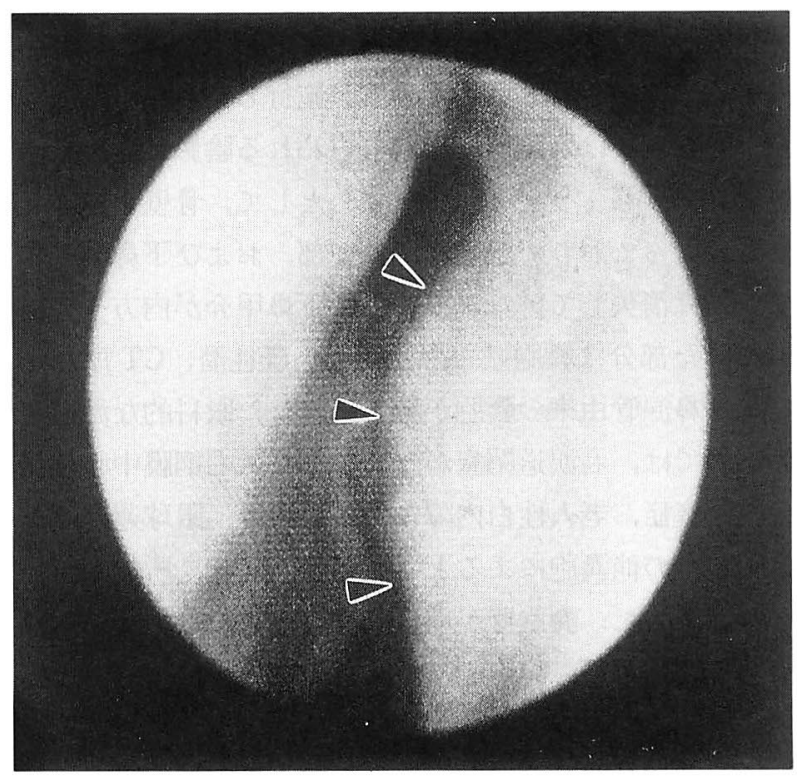

図1下鼻甲介が内方へ突出(矢印) 

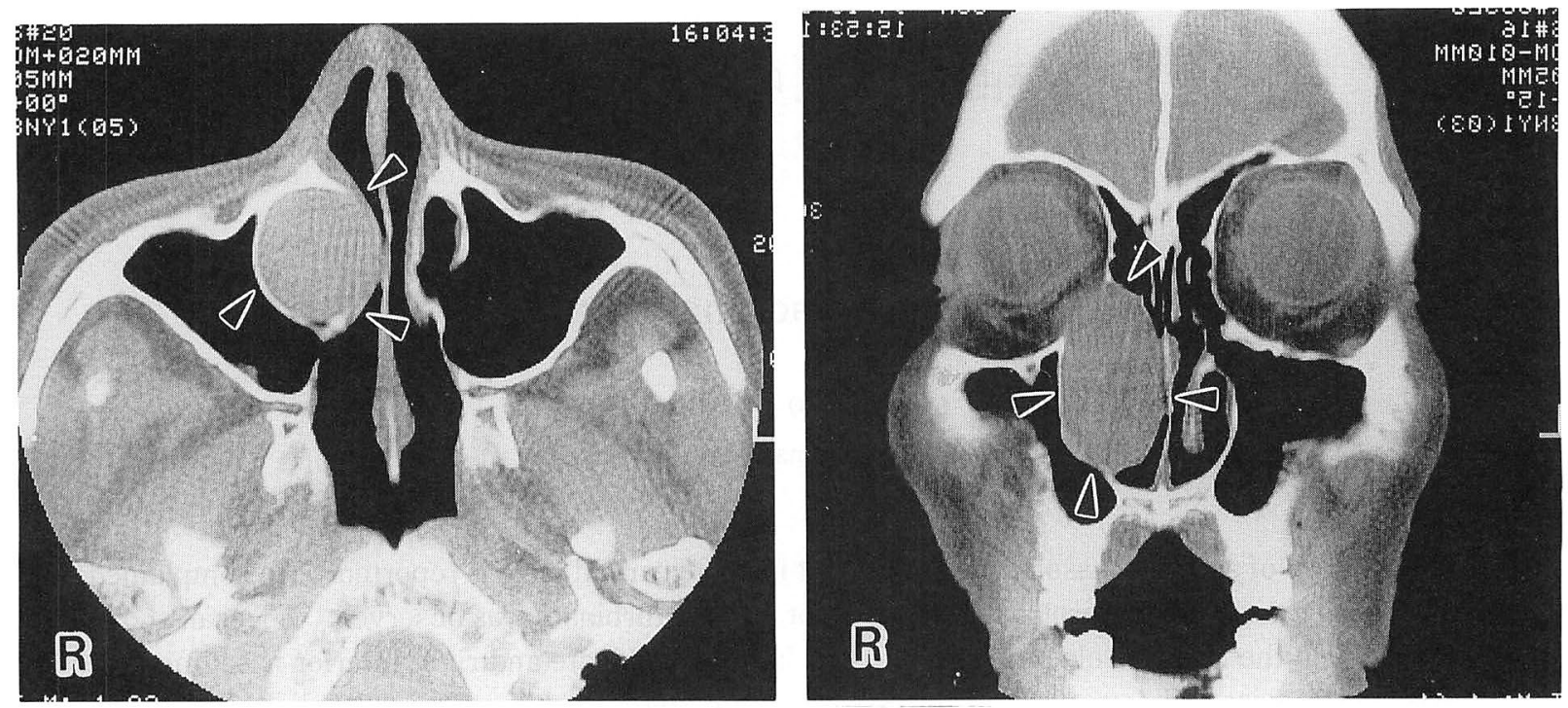

図 2 CT 像(左図: 水平断, 右図 : 冠状断)

上顎洞，篩骨洞とは別個に，蘘胞と思われる陰影(矢印)が認められる．眼窝骨壁の 1 部，および下鼻甲介骨の 1 部は消失 している。

痕と考光られたが，他に煩部の腫脹などは認められなか った．鼻腔を観察すると，下鼻甲介が内方へ突出してお り，下鼻道は確認できなかった(図 1)。この深部をファ イバーで観察すると, 突出部の後部は正常の下鼻甲介と なり，下鼻道，中鼻道拉よび中鼻甲介が確認された，鼻 腔粘膜は正常で鼻汁もほとんど認められなかった．霊胞 あるいは腫瘍が疑われたため CT 施行したところ，上領 洞，笠骨洞とは別個に，囊胞と思われる陰影が認められ た(図 2)。ちょうど鼻涙管を中心として，骨壁を拡大し た形になって括り，眼窩骨壁の一部，掠よび下鼻甲介骨 の一部は消失していた．視診上，下鼻甲介が内方へ突出 していた部分は霊胞壁と思われた。既往歴，CT 所見な どから鼻涙管由来の囊胞が考兄られた. 眼科的な涙道洗 浄試験では，右淚道閉塞が認められた。右網膜中心静脈 分枝閉塞症，老人性白内障はあるものの，眼球運動は正 常で，午の他囊胞によると考克られる症状，所見は認め られなかった．囊胞壁が前鼻孔より明視でき，また高龄 であることから，鼻内よりの開空術を施行することとし た.

1994年10月 27 日，局麻下に内視鏡下鼻内囊胞開空術を 施行した。まず骨成分の存在しないところに切開を入れ ると，膿性の内容物を入れて特り，囊胞内腔は滑らかで 出血やポリープは認められなかった。開空部分を広げ,
鼻腔と十分に交通がつくよらにして術を終えた，術後経 過良好で，鼻閉も改善している，術後の CT では，術前 の CT で囊胞と思われた部分が含気腔となり，固有鼻腔 と広く交通している(図 3$)$. 囊胞内容物の細菌学的検査

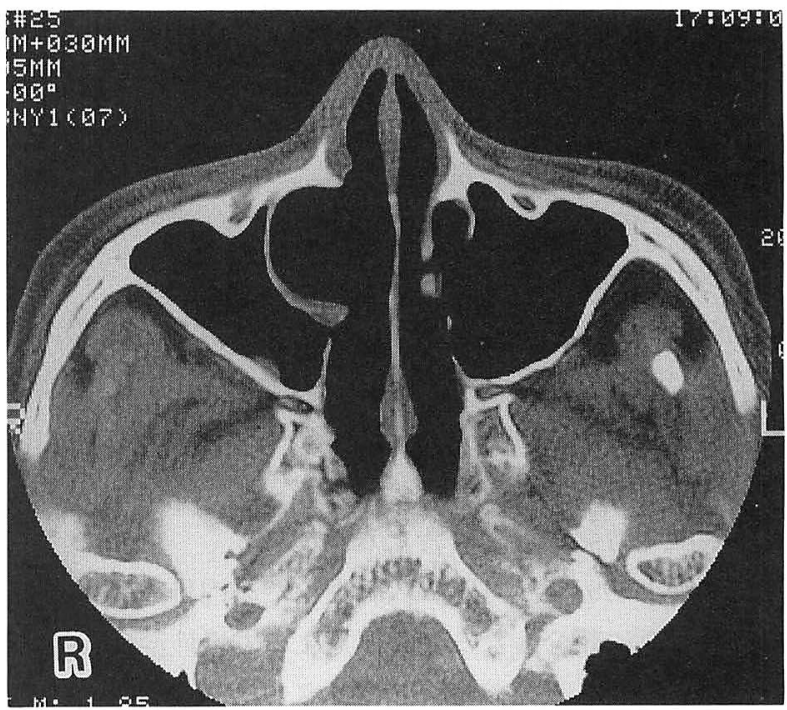

図 $3 \mathrm{CT}$ 像

術前の CT で裳胞と思われた部分が含気腔となり，固有 鼻腔と広く交通している。 
表 1 後天性鼻沪管裹胞

\begin{tabular}{|c|c|c|c|c|c|c|c|}
\hline 症例 & 報告年 & 報告者 & 年齢 & 性 & 主 訴 & 巽胞発生機序 & 治療法 \\
\hline 1 & 1988 & 吹上ら ${ }^{3)}$ & 41 & 男 & 右鼻閉, 流涙 & 不明 & $\begin{array}{l}\text { 罌胞摘出術 } \\
\text { (Denker 法) }\end{array}$ \\
\hline 2 & 1993 & 浅井ら ${ }^{4)}$ & 65 & 女 & 頭痛, 左頓部腫脹 & 沃瓖摘出術 & $\begin{array}{c}\text { 掣胞摘出術 } \\
\text { (Caldwell-Luc 法) }\end{array}$ \\
\hline 3 & 1995 & 自験例 & 79 & 男 & 右鼻閉 & $\begin{array}{l}\text { 涙䔩摘出術 } \\
\text { 外楊 }\end{array}$ & 内視鏡下開空術 \\
\hline
\end{tabular}

ではコリネバクテリウム族菌が検出された。嫌気性培養 は陰性であった，霊胞壁の病理学的検索では，慢性活動 性炎症で, 多数の漿液腺を伴い, やや繊維性な組織で, 表層に円柱上皮が認められた．悪性所見は認められなか った。

\section{考察}

先天性鼻沃管霊胞は新生児の流涙, 鼻閉, 呼吸困難の 原因として知られている．通常 1 側性で女児に多く，涙 震炎, 内眼角の青い柔らかい腫脹, 顔面蜂窩織炎, 下鼻 道に存在する腫瘤などが認められる122)。しかし，後天 性鼻涙管囊胞の報告は少なく，私が検索し得た範囲では 2 件のみであった314)(表 1 ).

鼻涙管は，涙囊下部の延長である Krause 弁を起始部 とし, Hasner 弁で覆われる鼻涙管口で終わる管である。 したがって 1 カ所のみが閉塞しても囊胞は形成されない が，いずれか 2 力所が閉塞すれば，襄胞が形成される可 能性がある. 先天性鼻涙管囊胞は, Hasner 弁と涙小管 の淚黹開口部に存在する Rosenmüller 弁の先天的閉鎖 が原因であると考兄られている5)。後天性鼻涙管襄胞の 報告では，症例 1 は原因掞よび閉鎖の部位が不明である. 症例 2 は, 本症例と同様沃囊摘出術の既往があり, 上部 はこのために閉鎖していた．下部の閉鎖機序は不明であ るが，慢性副鼻腔炎があるため，あるいは炎症性の癒着 があった可能性も考兄られる，本症例においては，上部 は沃㹕摘出術の際に閉鎖し，下部は，右鼻翼から頓部に かけて馬に蹴られた際に鼻涙管口の閉塞, 癒着を起こし て閉鎖し，嚷胞を形成したと考えられた. 病理学的にも， 鼻淚管由来の囊胞として矛盾しない所見が得られている. 治療であるが，先天性鼻涙管囊胞に対しては，自然退 縮も報告されているので，呼吸困難や涙哄炎が保存的に 対処できるようであれば経過を見る場合もある。しかし， 自然退縮しない場合や呼吸困難が強い例では涙管ブジー 法や鼻腔よりの内視鏡下開空術が行われている11677)．後
天性鼻涙管霊胞の報告では, 症例 1 は Denker 法に準じ て, 症例 2 は Caldwell-Luc 法に準じて䧶胞摘出術が施 行されている.すなわち, 口腔前庭よりアプローチし, 霊胞の摘出術を行っているが，上䫇洞粘膜を除去し，さ らに症例 1 では下鼻甲介の切除も行っている. 今回私は, 鼻内よりの開空術のみを行い, 上頸洞に操作を加えるこ とや䧶胞壁の粘膜の除去は行わなかった．それは，霊胞 壁が前鼻孔より明視できること，上㴿洞をはじめとする 副鼻腔に炎症所見が認められなかったこと，および高齢 であること，などの理由による．後天性鼻涙管糞胞に対 しても，鼻腔よりの内視鏡下開空術も試みられてょい術 式であろらと思われる.

$$
\text { まとめ }
$$

今回私は, 副鼻腔とは別個に存在した霊胞症例を経験 した. CT 検査で鼻涙管を中心として，骨壁を拡大した

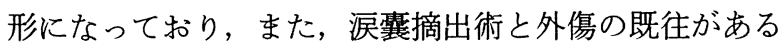
ことから，後天性の鼻涙管由来の囊胞が考兄られた，鼻 腔よりの内視鏡下開空術を施行し，良好な結果を得た。

稿を終えるに当たり，御助言をいただきました相川 通助教 授ならびに御校閲をいただきました大谷嚴教授に深謝いたし ます。

\section{引用文献}

1) Mansour AM, Cheng KP, Mamma JV, et al : Congenital dacryocele ; a collaborative review. Ophthalmology 98 : 1744 1751, 1991.

2) Rand PK, Ball WS Jr and Kulwin DR : Congenital nasolacrimal mucoceles; CT evaluation. Radiology $173: 691 \sim 694,1989$.

3 ）吹上忠祐, 江浦正郎, 猪川 勉, 他 : 鼻涙管由来と思われ 大慗胞症例. 日鼻科会誌 $26: 73,1988$.

4 ）浅井良三, 津田恵子 : 鼻涙管手術後に発生した術後性謈腫. 鐘紡記念病院紙 $9: 69 \sim 71,1993$. 
5 ) Jones LT and Wobig JL : Treatment of congenitally closed nasolacrimal ducts. Surgery of the eyelids and lacrimal system. pp 163 167, Aesculapius, Birmingham, 1976.

6 ) Grin TR, Mertz JS and Stass-Isern M: Congenital nasolacrimal duct cysts in dacryocystocele. Ophthalmology $98: 1238 \sim 1242,1991$.

7 ) Berkowitz RG, Grundfast KM and Fitz C : Nasal obstruction of the newborn revisited; clinical and subclinical manifestations of congenital nasolacrimal duct obstruction presenting as a nasal mas. Otolaryngol Head Neck Surg $103: 468 \sim 471,1990$.

(別刷請求先 : 鈴木知子 兵960 福島市桜木町4-15

済生会福島総合病院耳鼻咽喉科) 